\title{
Perilaku Konsumsi Upaya Meningkatkan Potensi Produk Deposito di Bank Syariah
}

\section{Tri Mulanto}

Perbankan Syariah Universitas Muhammadiyah Parepare, Indonesia

Email: trimsiuii@yahoo.co.id

\begin{abstract}
Abstrak
Perbankan syari'ah saat ini telah memiliki payung hukum yang kuat dengan hadirnya undang-undang nomor 21 tahun 2008 tentang perbankan syari'ah. Hal ini sangat berpengaruh terhadap eksistensi dari perbankan syari'ah yang semakin diminati oleh banyak kalangan.Bank syari'ah membutuhkan dana dalam menjalankan produk pembiayaannya. Deposito merupakan salah satu produk penghimpunan di bank syariah. Deposito di bank syariah terus mengalami pertumbuhan. Walaupun demikian bank syariah tetap harus meningkatkan produk deposito, untuk mencapai market share 5 persen. Untuk meningkatkan volume deposito bank syariah perlu memahami bentuk perilaku konsumsi masyarakat. Dari data yang ada kontribusi dana pihak ketiga bank syariah diberikan oleh produk deposito sebesar 71,15 persen.Penulisan ini menggunakan jenis deskriptif kualitatif, Batasan dalam tulisan ini difokuskan pada produk deposito di bank syari'ah perilaku konsumen.Tulisan ini menggunakan studi pustaka kajian dari berbagai sumber. Hasil dari tulisan ini bahwa deposito di bank syariah terus mengalami perkembangan, pada tahun 2015 pertumbuhan deposito di bank syariah mencapai 4,12 persen. Perilaku konsumsi memiliki banyakfaktor dan bisa memberi pengaruh terhadap peningkatan produk deposito di bank syariah. Sehingga bank syariah perlu memahami perilaku konsumsi masyarakat dalam upaya meningkatkan potensi pengembangan produk deposito di bank syariah.potensi pengembangan produk pembiayaan mudharabah di bank syari'ah masih sangat besar.Potensi pengembangan produk deposito masih sangat besar dan sangat luas.
\end{abstract}

\section{Abstract}

Bank of Shariah now has a solid legal with the presence of the law number 21 in 2008 about Bank of Shariah. This adversely affects the existence of the Shari'ah

Intizar, Vol. 22, No. 2, 2016 
Bank that increasingly catches interest many people. Bank of Shari'ah requires funds in running financing products. Deposits are ones' product accumulation in Islamic banks. Deposits in Islamic banks continued to grow. Nevertheless, Islamic banks still have to increase deposit products, to achieve a 5 percent market share. To increase the volume of deposits of Islamic banks need to understand the behaviors of consumption. From the available data the contribution of third party funds provided by the Islamic banks deposits amounted to 71.15 persen. This study uses a descriptive qualitative limitation. This paper is focused on products in Consumers Islamic bank deposits. This study uses literature review of various sources. The results of this paper that the deposits in Islamic banks continued to experienced growth, in 2015 the growth of deposits in Islamic banks reaches 4.12 percent. Consumer behavior has many factors and can give effect to an increase in deposit products in Islamic banks. So that Islamic banks need to understand the behavior of private consumption in order to increase the potential for product development of deposits in Bank of Shariah. The advantage of product development in Islamic bank financing is still enormous. The advantage of deposit product development is still very large and very spacious.

Keywords: Bank of Shariah, Deposit Products and Consumption Behavior

Seiring dengan perbaikan dan reformasi perbankan nasional pasca krisis ekonomi, perbankan syari'ah yang merupakan bagian dari perbankan nasional mulai memasuki babak baru implementasi sistem perbankan nasional dengan segala hambatan dan perkembangan yang secara berkala terus diperbaiki sesuai dengan syariat Islam. Perbankan syari'ah era reformasi dimulai dengan disetujuinya Undang-undang No.10 tahun 1998 tentang perbankan syari'ah. ${ }^{1}$ Kemudian disempurnakan dengan adanya undang-undang Perbankan Syari'ah nomor 21 tahun 2008.

Ide dasar sistem perbankan Islam sebenarnya dapat dikemukakan dengan sederhana.Operasi institusi keuangan Islam terutama berdasarkan pada prinsip PLS (porfit-and-loss-sharing bagi untung dan rugi). Prinsip bagi hasil ini dalam keuangan Islam sangat dianjurkan dan merupakan solusi yang pantas dan relefan untuk mengatasi masalah alokasi dana yang terbatas, baik yang berupa dana pinjaman atau tabungan dengan maksud supaya pengelolaan dan pembiayaan bisnis secara efektif dapat tercapai. Bank Islam tidak membebankan bunga, melainkan mengajak partisipasi dalam bidang usaha yang didanai.Para deposan

Intizar, Vol. 22, No. 2, 2016 
juga sama-sama mendapat bagian dari keuntungan bank sesuai dengan rasio yang telah ditetapkan sebelumnya. Dengan demikian ada kemitraan antara bank Islam dan para deposan di satu pihak, dan antara bank para nasabah investasi sebagai pengelola sumber daya para deposan dalam berbagai usaha produktif dipihak lain. $^{2}$

Alasan didirikannya bank syari'ah diantaranya karena keadilan yang terdapat pada bank syari'ah.Di kalangan investor Barat terjadi pergeseran paradigma dalam berinvestasi yaitu mereka tidak lagi berinvestasi karena alasan tertarik dengan bunga yang kelihatannya saja menjanjikan keuntungan berlipat ganda seketika.Namun kini mereka lebih kritis penghasilan yang mungkin diperoleh melalui metode institusi pemutaran uang, sehingga sistem bagi hasil yang diterapkan oleh bank syari'ah lebih logis dan fair bagi mereka.Dengan adanya bank syari'ah maka semua umat terutama umat Islam terhindar dari riba dalam kegiatan muamalahnya memperoleh kesejahteraan lahir batin dan sesuai dengan perintah agamanya.

Karakteristik sistem perbankan syariah yang beroperasi berdasarkan prinsip bagi hasil memberikan alternatif sistem perbankan yang saling menguntungkan bagi masyarakat dan bank, serta menonjolkan aspek keadilan dalam bertransaksi, investasi yang beretika, mengedepankan nilai-nilai kebersamaan dan persaudaraan dalam berproduksi, dan menghindari kegiatan spekulatif dalam bertransaksi keuangan. Dengan menyediakan beragam produk serta layanan jasa perbankan yang beragam dengan skema keuangan yang lebih bervariatif, perbankan syariah menjadi alternatif sistem perbankan yang kredibel dan dapat dinimati oleh seluruh golongan masyarakat Indonesia tanpa terkecuali. ${ }^{3}$

Bank syariah berperan dalam menghimpun dana dari masyarakat untuk keberlanjutan operasionalnya. Bank syariah telah memiliki produk penghimpunan dana (funding) yang diperoleh dari masyarakat. Kemudian, dana tersebut disalurkan kepada masyarakat yang membutuhkan dalam berbagai jenis produk pembiayaan (financing) di bank syariah. Produk funding tersebut meliputi produk giro, produk tabungan, dan produk deposito. Ketiga produk tersebut makin diminati oleh masyarakat hal terlihat dari berkembangnya produk tersebut. 


\section{Tabel $1^{4}$}

Perkembangan Dana Pihak Ketiga (DPK) Di Bank Syariah

\begin{tabular}{|c|c|c|c|c|}
\hline No & Jenis Dpk & $\begin{array}{c}\text { Desember } \\
\mathbf{2 0 1 4}\end{array}$ & $\begin{array}{c}\text { Desember } \\
\mathbf{2 0 1 5}\end{array}$ & Pertumbuhan \\
\hline 1 & Giro & 2136 & 3867 & $81,04 \%$ \\
\hline 2 & Tabungan & 51014 & 53448 & $4,77 \%$ \\
\hline 3 & Deposito & 135628 & 141329 & $4,20 \%$ \\
\hline 4 & Total & 188.778 & 198.644 & $5,23 \%$ \\
\hline
\end{tabular}

Sumber: OJK, Statistik Perbankan Syariah 2016

Dari data diatas menunjukkan bahwa pertumbuhan DPK tertinggi pada produk giro sebesar 81,04\% walaupun secara nominal paling kecil nilainya. Berbanding terbalik dengan deposito yang nominal sangat besar hanya saja persentase pertumbuhannya terkecil dibawah giro dan tabungan. Padahal jika dilihat secara keuntungan deposito lebih pas bagi bank syariah untuk memenuhi kebutuhan dana pembiayaannya. Deposito dana yang tidak dapat ditarik kapan saja tetapi sesuai dengan waktu yang telah ditentukan sehingga bank syariah lebih leluasa dalam mengelolah dana deposito.

Deposito adalah simpanan berjangka yang dikeluarkan oleh bank, yang penarikannya hanya dapat dilakukan dalam jangka waktu tertentu, sesuai dengan jangka waktu yang telah diperjanjikan sebelumnya.Seperti 1 bulan, 3 bulan, 6 bulan, 12 bulan, dan 24 bulan. Adapun yang dimaksud dengan deposito syari'ah adalah deposito yang dijalankan berdasarkan prinsip syari'ah dan berjalan sesuai dengan waktu yang telah disepakati dari awal.Dalam hal ini, Dewan Syari'ah Nasional MUI telah mengeluarkan fatwa bahwa deposito yang diperbolehkan dan dibenarkan adalah deposito yang berdasarkan prinsip mudharabah.

Bank syariah dituntut untuk bisa menghimpun dana pihak ketiga deposito untuk bisa menyalurkan dananya bisa memberikan pembiayaan yang lebih banyak, sehingga juga bisa meningkatkan profitabilitas dari perbankan syariah. Selain itu, deposito menjadi sarana investasi bagi nasabah yang menghendaki bagi hasil yang lebih besar. Perlu ada upaya bagi bank syariah untuk menarik minat nasabah agar mau memilih deposito syariah. Bank syariah perlu memahami bentuk perilatu konsumsi masyarakat. Faktor promosi merupakan salah satu faktor penentu keberhasilan program pemasaran sekaligus untuk menginformasikan kelebihan-kelebihan produk dan membujuk konsumen untuk membelinya. 
Betapapun berkualitasnya produk/jasa, bila konsumen belum pernah mendengarnya, maka mereka tidak akan pernah membelinya. ${ }^{5}$

Dari uraian diatas penulis tertarik untuk melakukan pendalaman mengenai analisis perilaku konsumsi terhadap potensi pengembangan produk deposito di bank syariah. Mengingat saat ini, market share bank syariah belum mencapai target 5 persen. Sehingga dibutuhkan upaya ekstra dari bank syariah untuk mampu memenuhi produknya baik itu produk funding maupun produk finacingnya. Untuk meningkatkan financing bank syariah membutuhkan funding yang besar pula, deposito menjadi produk yang paling baik untuk bisa memenuhi pembiayaan di bank syariah.

\section{Perilaku Konsumsi}

Perilaku konsumen terpusat pada cara individu mengambil keputusan untuk memanfaatkan sumber daya mereka yang tersedia (waktu, uang, usaha) guna membeli barang-barang yang berhubungan dengan konsumsi. ${ }^{6}$ Menurut Engel Et, Perilaku konsumen adalah tindakan yang langsung terlibat untuk mendapatkan, mengkonsumsi, dan menghabiskan produk dan jasa, termasuk proses keputusan yang mendahului dan mengikuti tindakan ini. ${ }^{7}$ Sedangkan Muhammad Muflih, Dalam Islam, perilaku seorang konsumen harus mencerminkan hubungan dirinya dengan Allah Swt. Seorang konsumen muslim akan mengalokasikan pendapatannya untuk memenuhi kebutuhan duniawi dan ukhrawinya. Konsumsi tidak dapat dipisahkan dari peranan keimanan. Peranan keimanan menjadi tolak ukur penting karena keimanan memberikan cara pandang dunia yang cendrung mempengaruhi kepribadian manusia, yang dalam bentuk perilaku, gaya hidup, selera, sikap-sikap terhadap sesama manusia, sumber daya, dan ekologi. Keimanan sangat mempengaruhi sifat, kuantitas, dan kualitas konsumsi baik dalam bentuk kepuasan material maupun spiritual. ${ }^{8}$

Batasan konsumsi dalam Islam sebagaimana diurai dalam Alquran surat Al Baqarah : 168-169. "Hai manusia, makanlah yang halal lagi baik dari apa yang terdapat dibumi dan janganlah kamu mengikuti langkah-langkah syaitan; karena sesungguhnya syaitan adalah musuh yang nyata bagimu. Sesungguhnya syaitan itu hanya menyuruh kamu berbuat jahat dan keji, dan mengatakan kepada Allah apa yang tidak kamu ketahui. (QS. Al Baqarah: 168-169).

Kebutuhan hidup itu harus terpenuhi secara wajar agar kelangsungan hidup berjalan dengan baik. ${ }^{9}$ Difirmankan dalam Alquran surat Al Maidah : 87. "Hai orang-orang yang beriman, janganlah kamu haramkan apa-apayang baik 
yang telah Allah halalkan bagi kamu, dan janganlah kamumelampaui batas.Sesungguhnya Allah tidak menyukai orang-orangyang melampaui batas. (QS. Al Maidah: 87)

Dari definisi diatas, dapat ditarik beberapa kesimpulan bahwa pengertian perilaku konsumen yaitu:

1) Perilaku konsumen menyoroti perilaku individu dan rumah tangga.

2) Perilaku konsumen menyangkut suatu proses keputusan sebelum pembelian serta tindakan dalam memeperoleh, memakai, mengkonsumsi, dan menghabiskan produk.

3) Mengetahui perilaku konsumen meliputi perilaku yang dapat diamati seperti jumlah yang dibelanjakan, kapan, dengan siapa, oleh siapa dan bagaimana barang yang sudah dibeli dikonsumsi. Juga termasuk variable-variabel yang tidak dapat diamati seperti nilai-nilai yang memiliki konsumen kebutuhan pribadi, persepsi, bagaimana mereka mengevaluasi alternatif, dan apa yang mereka rasakan tentang kepemilikan dan penggunaan produk yang bermacam-macam.

Perilaku konsumen merupakan perkembangan dari psikologi konsumen dalam penelitian yang merupakan perluasan pengambilan keputusan konsumen dalam bidang perilaku ekonomi dan psikologi ekonomi.

Dalam bank konsumen disebut dengan nasabah, nasabah adalah setiap orang yang datang ke bank untuk bertransaksi, setiap orang yang ke bank untuk mendapatkan informasi dan setiap orang yang ada di kantor (satu bagian, bagian lain, atau cabang lain). Pepatah mengtakan nasabah adalah raja, maka nasabah wajib dilayanin dengan tulus dan ikhlas. ${ }^{10}$

Menurut Kasmir, tujuan pemasaran bank secara umum adalah untuk: ${ }^{11}$

a. Memaksimalkan konsumsi atau dengan kata lain memudahkan dan merangsang konsumsi, sehingga dapat menarik nasabah untuk membeli produk yang ditawarkan secara berulang-ulang

b. Keputusan pembelian dari konsumen sangat dipengaruhi oleh faktor kebudayaan, sosial, pribadi, psikologi dari konsumen. Selain itu, juga di pengaruhi oleh beberapa ransangan pemasaran seperti unsur-unsur di dalam marketing mix dan ransangan lainnya seperti perekonomian, teknologi, politik, dan budaya. Sebagian besar adalah faktor-faktor yang tidak dapat dikendalikan oleh pemasar, tetapi harus benar-benar diperhitungkan.

Proses pengambilan keputusan dapat di pandang sebagai tiga tahap yang berbeda namun berhungan satu sama lain dipaparkan Leon schiffman dkk dalam 
bukunya yang berjudul perilaku konsumen. Tahap masukan mempengaruhi pengenalan konsumen melalui sumber informasi utama: usaha pemasaran perusahaan (produk itu sendiri, harganya, promosinya, dan di mana ia dijual). Tahap proses model memfokuskan berbagai faktor psikologis yang melekat pada individu (motivasi, persepsi, pengetahuan, kepribadian, dan sikap). Tahap keluaran kegiatan setelah pengambilan keputusan yang berhubungan erat: perilaku membeli dan evaluasi setelah membeli. ${ }^{12}$

Perilaku konsumsi seperti ini tentunya tidak dapat diterima begitu saja dalam konsep ekonomi islam. Konsumsi yang islami selalu berpedoman dengan ajaran islam. Di antara ajaran yang penting berkaitan dengan konsumsi, misalnya perlu memperhatikan orang lain. Hal lain adalah tujuan konsumsi itu sendiri di mana seorang muslim akan lebih mempertimbangkan mashlahah daripada utilitas. Pencapaian mashlahah merupakan tujuan dari islam (maqasid syariah), yang tentu saja harus menjadi tujuan dari kegiatan konsumsi. ${ }^{13}$

Perbedaan karakteristik manusia dalam berfikir, berkata, dan bertindak. Seseorang akan dikatakan baik bila perilakunya sesuai dengan ajaran agama, dan sebaliknya akan buruk bila perilakunya tidak sesuai dengan ajaran agama. Proses dari berfikir hingga bertindak sesuai dengan ajaran agama tentu erat kaitannya dengan kendali unsur-unsur manusia yang memiliki seseorang. ${ }^{14}$ Persepsi adalah peroses yang digunakan oleh individu untuk memilih, mengorganisasi, dan menginterprensi masukan informasi guna menciptakan gambaran dunia yang memiliki arti. ${ }^{15}$

Persepsi konsumen berkaitan erat dengan kesadarannya yang subyektif mengenai realitas sehingga apa yang dilakukan seorang konsumen merupakan reaksi terhadap persepsi subyektifnya, bukan berdasar pada realita yang objektif. Jika seorang konsumen berfikir mengenai realitas, itu bukanlah realitas yang sebenarnya, tetapi merupakan pikirannya mengenai realitas yang akan mempengaruhi tindakannya, seperti keputusan membeli sesuatu. ${ }^{16}$

Perintah-perintah Islam terhadap perilaku konsumsi dituntun oleh lima prinsip, yaitu: ${ }^{17} 1$ ) Prinsip Keadilan; 2) Prinsip Kebersihan; 3) Prinsip Kesederhanaa; 4) Prinsip Kemurahan Hati; dan 5) Prinsip Moralitas.

Kunci untuk memahami perilaku konsumen dalam Islam tidak terletak dengan hanya mengetahui hal-hal yang terlarang tetapi juga dengan menyadari konsep dinamika tentang sikap moderat dalam konsumsi yang dituntun oleh perilaku yang mengutamakan kepentinga orang lain, yaitu seorang konsumen

Intizar, Vol. 22, No. 2, 2016 
muslim. Larangan-larangan Islam mengenai makanan dan minuman harus dipandang sebagai usaha untuk memperbaiki perilaku konsumen. ${ }^{18}$

\section{Produk Deposito di Bank Syariah}

Adapun yang dimaksud dengan deposito syariah adalah deposito yang dijalankan dengan berdasarkan prinsip syari'ah.Dalam hal ini, Dewan Syari'ah Nasional MUI telah mengeluarkan fatwa yang menyatakan bahwa deposito yang diberikan adalah deposito yang berdaarkan prinsip mudharabah.Tertuang dalam Fatwa Dewan Syari'ah Nomor 03/ DSN-MUI/IV/2000.Sedangkan menurut BI dalam kodifikasi produk perbankan syariah disebutkan bahwa deposito adalah simpanan yang penarikannya hanya dapat dilakukan pada waktu tertentu berdasarkan perjanjian antara nasabah dengan bank dengan sistem akad yang disebut mudharabah. ${ }^{19}$

Inti akad dari akad mudharabah dalam produk simpanan yaitu kita sebagai pemilik dana (shahibul maal) dan bank syariah sebagai lembaga yang mengelolah dana kita (mudhrib), berikut penjelasan skema saving dengan akad mudharabah: 1) Dana yang kita sertakan dengan akad mudharabah akan dikelolah bank syariah. Caranya; 2) Bank syariah memberikan dana kepada nasabah pembayaran dengan akad mudharabah juga. Nasabah pembiyaan akan menggunakan dana tadi untuk modal usaha; 3) akan memberikan bagi hasil kepada bank syariah dari pendapatan/keuntungannya (revenue/profit sharing). Dengan begitu, bank syariah akan mendapat bagi hasil dari usaha nasabah pembiayaan. Dari sinilah bank syariah memperoleh pendapatan; 4) Total pendapatan/keuntungan bank syariah inilah yang akan dibagihasilkan dengan kita selaku shahibul maal. Dari uraian tersebut membuktikan bahwa melalui deposito juga terdapat unsur investasi, yaitu dimana seseorang memanfaatkan dananya untuk pendanaan suatu kegiatan yang dapat menghasilkan laba dan dibagikan melalui mudharabah.

Deposito syariah merupakan suatu bentuk investasi yang sederhana dimana pemilik dana tidak terjun langsung dalam pendanaan suatu kegiatan namun melalui jasa perbankan.syariah. Secara tidak langsung bahwa alur dan tujuan antara deposito dan investasi itu sama, karena keduanya merupakan suatu kegiatan pendanaan suatu kegiatan produktif dan modal yang ditanamkan itu diharapkan dapat bertambah sesuai dengan profit yang diperoleh dari hasil kegiatan. Keduanya merupakan kegiatan penundaan konsumsi pada saat itu untuk memperoleh nilai atau kepuasan lebih dimasa akan datang. Deposito syariah dan

Intizar, Vol. 22, No. 2, 2016 
investasi merupakan kegiatan yang dapat menumbuhkan sektor rill lebih khusus kegiatan produktif domestik dan kegiatan itu sesuai dengan anjuran syariah.

Melalui dana yang disalurkan melalui perbankan syariah akan dikelolah sebaik mungkin untuk menghasilkan keuntungan yang besar kemudian dibagihasilkan sesuai dengan akad awal. Jadi jelas bahwa deposito syariah terdapat unsur investasi didalamnya, yaitu penyaluran dana untuk suatu kegiatan produktif sehingga menghasilkan hasil yang lebih besar dimasa akan datang. Juga dengan deposito mengantisipasi akan kebutuhan dimasa akan datang yang akan semakin sulit ditentukan keadaannya, terutama jika kebutuhan pada naik.

Besar kecilnya bagi hasil yang akan kita terima dipengaruhi oleh beberapa faktor, yaitu: ${ }^{20}$ 1) Keuntungan Bank; 2) Besarnya nisbah bagi hasil untuk kita; 3) Jumlah nominal deposito kita; dan 4) Rata-rata deposito yang terkumpul dalam periode tertentu.

Sifat-sifat dari deposito syariah

a. Deposito syariah atau lebih tepatnya deposito investasi mudharabah merupakan investasi melalui simpanan pihak ketiga (perseorangan atau badan hukum) yang penarikannya hanya dapat dilakukan dalam jangka waktu tertentu jatuh tempo, dengan mendapatkan imbalan bagi hasil.

b. Imbalan dibagi dalam bentuk berbagi pendapatan (revenue sharing) atas penggunaan dana tersebut secara syariah dengan proporsi pembagian yang telah disepakati antara deposan dengan pihak bank syariah.

c. Jangka waktu deposito mudharabah berkisar antara 1 bulan, 3 bulan, 6 bulan dan 12 bulan.

\section{Contoh Perhitungan Kegiatan Deposito Syariah}

Pada tanggal 1 desember 1994 kita menyimpan uang di bank syariah dalam bentuk deposito sebesar Rp 10.000.000. Jangka waktu penyimpanan selama satu bulan dengan nisbah bagi hasil antara nasabah dengan bank syariah 57\%: $43 \%$. Keuntungan yang diperoleh bank syariah untuk deposito satu bulan sebesar Rp. 20.000.000 dan rata-rata deposito jangka satu bulan adalah Rp. 950.000.000.berdasarkan data tersebut, nominal bagi hasil yang akan diperoleh nasabah sebesar:

$\{\mathrm{Rp} 10.000 .000\} \times \mathrm{Rp} 20.000 .000 \times$ X 57\% $=120.000$ $\{\operatorname{Rp} 950.000 .000\}$

Intizar, Vol. 22, No. 2, 2016 
Tabel 2

Perkembangan deposito di Bank Syariah

\begin{tabular}{|l|l|c|c|l|}
\hline No & $\begin{array}{c}\text { Jenis Deposito } \\
\text { Mudharabah }\end{array}$ & $\begin{array}{c}\text { Juni } \\
\mathbf{2 0 1 4}\end{array}$ & $\begin{array}{r}\text { Juni } \\
\mathbf{2 0 1 5}\end{array}$ & Pertumbuhan \\
\hline 1 & Deposito 1 Bulan & 98.407 & 101.622 & $3.27 \%$ \\
\hline 2 & Deposito 3 Bulan & 15.427 & 16.588 & $7,52 \%$ \\
\hline 3 & Deposito 6 Bulan & 5.084 & 6.904 & $35,79 \%$ \\
\hline 4 & Deposito 1 Tahun & 5.848 & 4.792 & $-18,057 \%$ \\
\hline 5 & Jumlah Deposito & 124.766 & 129.906 & $4,12 \%$ \\
\hline
\end{tabular}

Sumber: OJK Statistik Perbankan Syariah, Juni 2015 (data diolah)

Dari data diatas menunjukkan akan laju perkembangan dari deposito di bank Syariah. Dari waktu kewaktu deposito di bank syariah terus mengalami perkembangan. Meskipun terlihat pada deposito pada periode yang sama mengalami penurunan sekitar 18\%, tapi secara kesuluruhan deposito di bank syariah terus mengalami pertumbuhan yang cukup baik. Nampak dari total jumlah dari deposito keseluruhan (satu bulan, tiga bulan, enam bulan, dan satu tahun) mengalami perkembangan sekitar $4,12 \%$. Hal ini membuktikan bahwa minat masyarakat terhadap produk deposito di Bank Syariah teus berkembang secara baik.

\section{Perilaku Konsumsi terhadap Potensi Peningkatan Produk Deposito di Bank Syariah}

Dalam bank konsumen disebut dengan nasabah, nasabah adalah setiap orang yang datang ke bank untuk bertransaksi, setiap orang yang ke bank untuk mendapatkan informasi dan setiap orang yang ada di kantor (satu bagian, bagian lain, atau cabang lain). Pepatah mengtakan nasabah adalah raja, maka nasabah wajib dilayanin dengan tulus dan ikhlas. ${ }^{21}$

Menurut Kasmir, tujuan pemasaran bank secara umum adalah untuk: $:^{22}$

a. Memaksimalkan konsumsi atau dengan kata lain memudahkan dan merangsang konsumsi, sehingga dapat menarik nasabah untuk membeli produk yang ditawarkan secara berulang-ulang.

b. Memaksimalkan kepuasan pelanggan melalui berbagai pelayanan yang diinginkan nasabah.

c. Memaksimukan pilihan (ragam produk) dalam arti bank menyediakan berbagai jenis produk bank sehingga nasabah memiliki beragam pilihan. 
d. Memaksimumkan mutu hidup dengan memberikan berbagai kemudahan kepada nasabah dan menciptakan iklim yang efisien.

Keputusan pembelian menurut Schiffman, Kanuk (2004, p.547) adalah pemilihan dari dua atau lebih alternatif pilihan keputusan pembelian, artinya bahwa seseorang dapat membuat keputusan, haruslah tersedia beberapa alternatif pilihan. Keputusan untuk membeli dapat mengarah kepada bagaimana proses dalam pengambilan keputusan tersebut itu dilakukan. Bentuk proses pengambilan keputusan tersebut dapat digolongkan sebagai berikut:

1. Fully Planned Purchase, baik produk dan merek sudah dipilih sebelumnya. Biasanya terjadi ketika keterlibatan dengan produk tinggi (barang otomotif) namun bisa juga terjadi dengan keterlibatan pembelian yang rendah (kebutuhan rumah tangga). Planned purchase dapat dialihkan dengan taktik marketing misalnya pengurangan harga, kupon, atau aktivitas promosi lainnya.

2. Partially Planned Purchase, bermaksud untuk membeli produk yang sudah ada tetapi pemilihan merek ditunda sampai saat pembelajaran. Keputusan akhir dapat dipengaruhi oleh discount harga, atau display produk.

3. Unplanned Purchase, baik produk dan merek dipilih di tempat pembelian. Konsumen sering memanfaatkan katalog dan produk pajangan sebagai pengganti daftar belanja. Dengan kata lain, sebuah pajangan dapat mengingatkan sesorang akan kebutuhan dan memicu pembelian (Engel, F. James, et.al, 2001, pp.127-128). ${ }^{23}$ Sedangkan Menurut James F. Engel Roger D. Blackwell - Paul W. Miniard dalam Saladin (2003 : 19) terdapat tiga faktor yang mempengaruhi perilaku konsumen yaitu $:^{24}$

a. Pengaruh lingkungan, terdiri dari budaya, kelas sosial, keluarga dan situasi. Sebagai dasar utama perilaku konsumen adalah memahami pengaruh lingkungan yang membentuk atau menghambat individu dalam mengambil keputusan berkonsumsi mereka. Konsumen hidup dalam lingkungan yang kompleks, dimana perilaku keputusan mereka dipengaruhi oleh keempat faktor tersebut diatas.

b. Perbedaan dan pengaruh individu, terdiri dari motivasi dan keterlibatan, pengetahuan, sikap, kepribadian, gaya hidup, dan demografi. Perbedaan individu merupkan faktor internal (interpersonal) yang menggerakkan serta mempengaruhi perilaku. Kelima faktor tersebut akan memperluas pengaruh perilaku konsumen dalam proses keputusannya. 
c. Proses psikologis, terdiri dari pengolahan informasi, pembelajaran, perubahan sikap dan perilaku. Ketiga faktor tersebut menambah minat utama dari penelitian konsumen sebagai faktor yang turut mempengaruhi perilaku konsumen dalam penambilan keputusan pembelian.

Keputusan pembelian dari konsumen sangat dipengaruhi oleh faktor kebudayaan, sosial, pribadi, psikologi dari konsumen. Selain itu, juga di pengaruhi oleh beberapa ransangan pemasaran seperti unsur-unsur di dalam marketing mix dan ransangan lainnya seperti perekonomian, teknologi, politik, dan budaya. Sebagian besar adalah faktor-faktor yang tidak dapat dikendalikan oleh pemasar, tetapi harus benar-benar diperhitungkan. ${ }^{25}$

Proses pengambilan keputusan dapat di pandang sebagai tiga tahap yang berbeda namun berhungan satu sama lain dipaparkan Leon schiffman dkk dalam bukunya yang berjudul perilaku konsumen. Tahap masukan mempengaruhi pengenalan konsumen melalui sumber informasi utama: usaha pemasaran perusahaan (produk itu sendiri, harganya, promosinya, dan di mana ia dijual). Tahap proses model memfokuskan berbagai faktor psikologis yang melekat pada individu (motivasi, persepsi, pengetahuan, kepribadian, dan sikap). Tahap keluaran kegiatan setelah pengambilan keputusan yang berhubungan erat: perilaku membeli dan evaluasi setelah membeli. ${ }^{26}$

Kepala Departemen Perbankan Syariah Otoritas Jasa Keuangan (OJK) Ahmad Buchory mengatakan, saat ini market share banksyariahdi Indonesia sekitar 5\% dari total aset bank secara nasional. Sementara, jumlah nasabah bank syariah saat ini masih di bawah 10 juta orang, sehingga potensi peningkatan nasabah perbankan syariah masih sangat besar mengingat jumlah penduduk usia produktif Indonesia terus bertambah. ${ }^{27}$ Potensi pengembangan produk bank syariah masih sangat besar khususnya untuk produk deposito. Dengan cara bank syariah harus mengamati pola perilaku konsumen dalam memilih suatu produk. Dengan demikian bank syariah akan menyajikan produk yang mampu mengakomodir kebutuhan nasabah akan jasa perbankan syariah. Dengan mengetahui perilaku konsumsi bank syariah dapat mengembangkan produknya khususnya produk deposito yang menjadi produk penghimpunan dana.

Intizar, Vol. 22, No. 2, 2016 


\section{Kesimpulan}

Produk deposito di bank syariah terus mengalami pertumbuhan secara nominal. Pada tahun 2015 jumlah deposito bank syariah mencapai 129.906.000.000.000 atau tumbuh sebesar 4,12\% dari tahun 2014.

Perilaku konsumsi ditentukan oleh beberapa faktor. Perilaku konsumsi dapat mempengaruhi potensi pengembangan produk deposito di bank syariah. Bank syariah perlu memahami perilaku konsumsi masyarakat, karena potensi pengembangan produk bank syariah masih sangat besar. Dengan memahami pola perilaku komsumsi bank syariah bisa mengembangkan produk deposito yang dimilikinya dan meningkatkan minat masyarakat dalam memilih produk deposito syariah. 


\section{Endnote}

${ }^{1}$ Muhammad Syafi'i Antonio, Bank Syariah: Dari Teori ke Praktik., (Jakarta: Gema Insani Press, 2001), hlm. 26

${ }^{2}$ Latifa M. Algaoud dan Mervyn K. Lewis, Perbankan Syariah, Prinsip, Praktik, Prospek, (Jakarta: PT. Serambi Ilmu Semesta, 2001), hlm. 9-10

${ }^{3}$ Diakses dari http://www.bi.go.id/web/id/Perbankan/Perbankan+Syariah/Pada tanggal 18 pebruari 2011

${ }^{4}$ Otoritas Jasa Keuangan. Statistik Perbankan Syaria 2015

${ }^{5}$ Tjiptono, Fandi .Pemasaran Jasa.(Malang: Bayu Media, 2002), hal. 219.

${ }^{6}$ Leon G. Schiffman dkk., Conssumer Behavior, edisi 15, (USA: Prentice Hall International, 1997), hal. 6.

${ }^{7}$ James F. Engel dkk., Consumer Behavior, jilid 6, (Jakarta:Binarupa Aksara, 1994.), I: 3 .

${ }^{8}$ Muhammad Muflih, Perilaku Konsumen Dalam Perspektif Ilmu Ekonomi Islam, (Jakarta: PT RajaGrafindo Persada,2006), hal. 4-12.

${ }^{9}$ Ibid.Hal 15.

${ }^{10}$ Muhammad, Manajemen Bank Syaraih, (Yogyakarta: AMP YKPN,2005) hal. 225.

${ }^{11}$ Setiadi, "Perilaku Konsumen: Konsep dan Implikasi untuk Strategi dan Penelitian Pemasaran”. (Jakarta: Prenada Media, 2005), hal.11.

${ }^{12}$ Leon G. Schiffman dkk, Perilaku Konsumen, Bambang Sarwiji (ed.), Cet. IV, (ttp.: PT Macanan Jaya Cemerlang, 2008, 7), hal 7-8..

${ }^{13}$ Pusat Pengkajian dan Pengembangan Ekonomi Islam (P3EI) UII, Ekonomi Islam, (Jakarta: PT. Raja Grafindo Persada, 2008), hal.128.

${ }^{14}$ Muhammad Muflih, Perilaku..., hal. 51.

${ }^{15}$ Philip Kolter, Manajemen Pemasaran, Benyamin Molan (ed.), Cet. III, (ttp.: PT Macanan Jaya Cemerlang, 2008, 7), hal 228.

${ }^{16}$ Ibid. hal. 91-92

${ }^{17}$ Abdul Mannan, Teori dan Praktek Ekonomi Islam, ( Yogyakarta: PT. Dana Bhakti Wakaf, 1997), hal.45.

${ }^{18}$ Ibid, hal. 51

${ }^{19}$ Dikutip dari http://andhysukma.com/investasi-deposito-syariah/ pada tanggal 9 April 2011

${ }^{20}$ Dwi Suwiknyo, How To Manage My Money Bikin Hidupmu Penuh Surplus, ( Yogyakarta: TrustMedia, 2008), hal. 94.

${ }^{21}$ Muhammad, Manajemen Bank Syaraih, (Yogyakarta: AMP YKPN,2005) hal. 225.

${ }^{22}$ Kasmir.Pemasaran Bank, Edisi Pertama, Cetakan Kedua (Jakarta: Kencana, 2005), hal. 66.

23 Dikutip dari http://jurnal-sdm.blogspot.com/2009/06/faktor-faktor-yangmempengaruhi.htmlpada tangga 2 september 2016.

24 Dikutip dari http://teddykw2.wordpress.com/2008/03/01/faktor-faktor-yangmempengaruhi-perilaku-konsumen/, pada tanggal 2 sepetember 2016.

${ }^{25}$ Setiadi, "Perilaku Konsumen: Konsep dan Implikasi untuk Strategi dan Penelitian Pemasaran”. (Jakarta: Prenada Media, 2005), hal.11.

Intizar, Vol. 22, No. 2, 2016 
${ }^{26}$ Leon G. Schiffman dkk, Perilaku Konsumen, Bambang Sarwiji (ed.), Cet. IV, (ttp.: PT Macanan Jaya Cemerlang, 2008, 7), hal 7-8.

27 Dikutip dari http://ekbis.sindonews.com/read/964020/34/ojk-market-share-banksyariah-5-1423810057pada tanggal 2 September 2016

\section{Daftar Pustaka}

\section{Al-Qur'an}

Antonio, Muhammad Syafii. (2000). Bank Islam: Teori dan Praktek. Jakarta: Gema Insani Press.

Aisyah, Siti, dkk. (2009) .Hubungan Antara Citra, Fasilitas dan Pelayanan Terhadap Tingkat Kepuasan Nasabah di Perbankan Syariah” makalah disampaikan pada nasional sistem ekonomi islam IV, diselenggarakan oleh P3EI Fakultas Ekonomi UII, Yogyakarta.

Algaoud Latifa M. dan Mervyn K. Lewis. (2001). Perbankan Syariah, Prinsip, Praktik, Prospek. Jakarta: PT. Serambi Ilmu Semesta.

Bank Indonesia., (2000). Penelitian Potensi, Preferensi dan Perilaku Masyarakat Terhadap Bank Syariah di Wilayah Jawa Tengah dan DIY.Semarang : LPPusat Penelitian dan Kajian Pembangunan UNDIP.

Engel, James F. dkk. (1994). Consumer Behavior. jilid 6. Jakarta: Binarupa Aksara.

Farizal. (2010). Pengembangan Kompetensi SDM Perbankan Syariah Melalui Corporate University. Yogyakarta: Forum Riset Perbankan Syariah II.

http://www.bi.go.id/web/id/Perbankan/Perbankan+Syariah/ Pada tanggal 18 pebruari 2011

http://ekbis.sindonews.com/read/964020/34/ojk-market-share-bank-syariah-51423810057pada tanggal 2 September 2016

http://teddykw2.wordpress.com/2008/03/01/faktor-faktor-yang-mempengaruhiperilaku-konsumen/, pada tanggal 2 sepetember 2016.

http://jurnal-sdm.blogspot.com/2009/06/faktor-faktor-yangmempengaruhi.htmlpada tangga 2 september 2016.

http://andhysukma.com/investasi-deposito-syariah/ pada tanggal 9 April 2011

Kasmir. (2005). Pemasaran Bank, Edisi Pertama. Cetakan Kedua. Jakarta: Kencana.

Mannan, Abdul. (1997). Teori dan Praktek Ekonomi Islam.Yogyakarta: PT. Dana Bhakti Wakaf. 
Muflih, Muhammad. (2006). Perilaku Konsumen Dalam Perspektif Ilmu Ekonomi Islam. Jakarta: PT Raja Grafindo Persada.

Muiszudin. (2009). Pengembangan Perbankan Syariah Dalam Perspektif Budaya, Nasional Sistem Ekonomi Islam IV. Yogyakarta: P3EI Fakultas Ekonomi UII

Muhammad. (2005). Manajemen Bank Syaraih. Yogyakarta: AMP YKPN.

Otoritas Jasa Keuangan. Statistik Perbankan Syaria 2015.

Philip Kolter. (2008). Manajemen Pemasaran, Benyamin Molan (ed.), Cet. III, ttp.: PT Macanan Jaya Cemerlang.

Prabowo. Yudho. (2009). Analisis Resiko dan Pengembalian Hasil pada Perbankan Syariah: Aplikasi Metode VaR dan RAROC pada Bank Syariah Mandiri. Jurnal Ekonomi Islam La_Riba Vol.111. No. 1. Yogyakarta: Fakultas Ilmu Agama Islam UII.

Schiffman, Leon G dan Kanul Leslie Lazar. (2008). Consumre Behaviour. Bambang Sarwiji (terj.), Perilaku Konsumen. Indonesia: PT Macanan Jaya Cemerlang.

Setiadi, Nugroho J. (2005). Perilaku Konsumen: Konsep dan Implikasi untuk Strategi dan Penelitian Pemasaran. Jakarta: Prenada Media.

Suwiknyo, Dwi. (2008). How To Manage My Money Bikin Hidupmu Penuh Surplus. Yogyakarta: TrustMedia.

Tjiptono, Fandi. (2002). Pemasaran Jasa. Malang: Bayu Media.

Yudi, Sutarso, dkk. Peranan Penggunaan Prinsip Syari'ah dan Budaya dalam Model Kualitas Jasaloyalitas pada Perbankan Syari'ah.Makalah disampaikan pada Forum Riset Perbankan Syaria'ah II 2010, diselenggarakan oleh IPIEF Fakultas Ekonomi UMY, Yogyakarta, 9 desember 2010. 